\title{
Voltaire, Genebra e as Ideias republicanas
}

Lorenzo Bianchi

lbianchi@unior.it

Università degli Studi di Napoli L’Orientale, Nápoles, Itália

resumo 0 presente artigo visa explorar as ricas relações entre Voltaire e Genebra, destacando as questões e o contexto que formam a obra Ideias republicanas e seu combate pela tolerância.

palavras-chave Voltaire; Genebra; tolerância; política; história

I. "Para dizer em uma palavra, muitos pastores de Genebra têm como religião somente um perfeito socianismo, rejeitando tudo aquilo que chamamos mistérios, e imaginando que o primeiro princípio de uma religião verdadeira é não propor nenhuma crença que se choque com a razão: mesmo quando são pressionados sobre a necessidade da revelação, este dogma tão essencial do cristianismo, muitos a substituem pelo termo utilidade, que lhes parece mais doce; se nisso eles não são ortodoxos, são, ao menos, coerentes com seus princípios. Um clérigo que pensa assim deve ser tolerante, e isso é realmente suficiente para ser malvisto pelos ministros das outras igrejas reformadas. Podemos dizer ainda, sem pretender aceitar a religião de Genebra, que há poucos países onde os teólogos e os eclesiásticos sejam mais inimigos da superstição. Em compensação, como a intolerância e a superstição só servem para multiplicar os incrédulos, lamenta-se menos em Genebra sobre os progressos da incredulidade que em outros lugares, o que não deve surpreender: lá a religião está quase reduzida à adoração de um só Deus, ao menos na casa de quase todos aqueles que não são do povo: o respeito por J.C. e pelas Escrituras é, talvez, a

Recebido em 02 de junho de 2012. Aceito em 10 de agosto de 2012.

Traduzido por Pedro Falleiros Heise (texto em italiano) e Carolina Noto (citações em francês). doispontos, Curitiba, São Carlos, vol. 9, n. 3, p.45-67, dezembro, 2012 
única coisa que distingue de um puro deísmo o cristianismo de Genebra." (D’ALEMBERT, 1757, p. 578ab).

Estas afirmações de d'Alembert - que se leem no verbete "Genebra" da Enciclopédia, publicada em 1757, no sétimo tomo da obra - escandalizaram os leitores genebrinos e foram interpretadas como diretamente influenciadas pelo filósofo de Ferney, com quem d'Alembert esteve nas semanas que passou em Genebra, em agosto de 1756, a fim de recolher a documentação necessária para seu artigo sobre a cidade de Calvino. ${ }^{1}$ De qualquer modo, imediatamente depois destes julgamentos sobre a teologia calvinista que parecia tender a um indeferentismo racionalista, o verbete "Genebra" conclui com algumas interessantes apreciações sobre a república suíça:

“Talvez não dedicaremos tão grandes artigos às mais vastas monarquias; mas aos olhos do filósofo a república das abelhas não é menos interessante que a história dos grandes impérios, e talvez seja somente nos pequenos estados que podemos encontrar o modelo de uma administração política perfeita. Se a religião não nos permite pensar que os genebrinos tenham trabalhado de maneira eficaz para sua felicidade no outro mundo, a razão nos obriga a crer que eles são quase tão felizes quanto se pode ser lá: 'O fortunatos nimium, sua si bona norint!'”’

(D'ALEMBERT, 1757, p. 578b).

Em uma carta a Pierre Robert Le Cournier de Cideville, de 12 de abril de 1756,Voltaire propõe uma avaliação análoga sobre Genebra, cidade em que se seguiria um "cristianismo razoável" e se adoraria o Ser supremo: "Genebra não é mais a Genebra de Calvino. É uma cidade cheia de verdadeiros filósofos. O cristianismo razoável de Locke é a religião de quase todos os ministros e a adoração de um ser supremo ligado à moral é a religião de quase todos magistrados." ${ }^{2}$

Para d'Alembert e para Voltaire, então, nos anos de 1756-57, Genebra representa uma república ativa e feliz que, em sua classe intelectual, segue uma religião mais semelhante ao deísmo que ao cristianismo.

Estas afirmações tiradas da Enciclopédia e do epistolário voltairiano podem se tornar um útil ponto de partida para tentar seguir as relações - e as oscilações - que Voltaire mantém com a cidade suíça e para captar ao mesmo tempo, a partir de um texto como as Ideias republicanas (que pode 
ser datado de fim de 1765), alguns temas políticos que para o pensador de Ferney acabam se concentrando nos anos sessenta, ao redor do motivo central e irrenunciável da tolerância.

As relações entre Voltaire e Genebra marcam, de fato, grande parte da vida do filósofo francês. São vinte e quatro anos desde a primeira entrada de Voltaire em Genebra aos 12 de dezembro de 1754 - quando é acolhido pelo conselheiro François Tronchin, irmão do banqueiro Jean-Robert e primo do médico Théodore - até seu retorno a Paris em 1778, ano de sua morte. E se num primeiro momento o filósofo adquire, graças ao banqueiro Jean-Robert Tronchin, a quinta "Les Délices" - as leis genebrinas proibiam, no território da república, qualquer posse por parte de um católico -, em seguida, graças também às tensões e às incompreensões que houve entre Voltaire e as autoridades religiosas e civis de Genebra - nas quais a polêmica sobre o teatro e as reações à publicação do artigo "Genebra" da Enciclopédia desempenhariam um papel importante -, Voltaire abandona a república suíça para se transferir à quinta de Ferney, em território francês, mas situado a poucas milhas de Genebra, que é adquirida - junto com Tourney - em 1758. Esta localização singular, francesa para todos os efeitos, mas bastante próxima de Genebra, devia permitir que Voltaire mantivesse um papel privilegiado na vida cultural e política da cidade suíça. Assim, as casas do filósofo francês são pontos de visitas contínuas e a boa sociedade genebrina participa das representações teatrais que se realizam antes, a partir de 1759 , no pequeno teatro de Tourney, e depois, a partir de 1762, no mais amplo e acolhedor teatro de Ferney.Voltaire intervém igualmente por diversas vezes nas lutas políticas que dividem Genebra com renovado ardor a partir de 1762.

A situação política de Genebra era, de fato, complexa. ${ }^{3}$ A república tinha se transformado numa aristocracia dominada por poucas famílias em que o Conselho Geral ("Conseil Général”), ou seja, a assembleia de todos os cidadãos, tinha perdido as prerrogativas originárias. O poder era exercido pelo Pequeno Conselho ("Petit Conseil") e pelo Grande Conselho ou Conselho dos Duzentos ("Grand Conseil" ou "Conseil des Deux-Cent"). O primeiro, composto por vinte e cinco magistrados, exercia o poder executivo e nomeava os "syndics", os membros do governo, enquanto o Grande Conselho exercia o poder legislativo. Mas os membros do Grande Conselho eram nomeados pelo Pequeno Conselho, de cuja eleição não 
participava o Conselho Geral. Deste modo se tinha formado um patriciado ou uma aristocracia que de fato exercia um direito de veto ("droit negatif”) em comparação a uma burguesia que, ao contrário, defendia o próprio direito de apresentar recursos ou protestos ("représentations"). Donde os nomes dados aos patrícios e aos burgueses de "négatifs" e "représentants". Mas, ao lado desta oposição entre uma burguesia de "représentants" com direitos intensamente limitados e uma aristocracia de "négatifs" que exercia um domínio oligárquico, colocava-se o protesto de um povo de cidadãos - "sujets" - e de operários - "habitants" e "natifs" privados dos direitos políticos. ${ }^{4}$

Ora, nesta difícil situação política e social da Genebra dos anos sessenta, Voltaire intervém de maneira diversificada, apoiando no começo os "représentants" contra os "négatifs", com a tentativa de realizar uma mediação política pessoal entre os dois grupos - e esta será a posição que surgirá nas Ideias republicanas - para depois ficar do lado dos "natifs". E tudo isso não sem oscilações ou equívocos, que o próprio Voltaire bem exprime numa carta a d'Argental de 12 de maio de 1766:

"Os nativos dizem que eu tomo o partido dos burgueses; os burgueses creem que eu tomo o partido dos nativos. Os nativos e os burgueses acham que eu tive muita deferência para com o conselho. O conselho diz que eu tenho muita amizade com os nativos e os burgueses. Os burgueses, os nativos e os conselheiros não sabem nem o que querem, nem o que fazem, nem o que dizem." (VOLTAIRE, D13294).

II. Este quadro complicado e nem um pouco linear deve ser considerado como momento imprescindível não só para situar historicamente um texto sem dúvida de interesse como as Ideias republicanas, mas também para realizar uma reconstrução genética da escrita voltairiana, que constantemente toma como ponto de partida elementos polêmicos e precisos para desenvolver as próprias exigências filosóficas ou políticas. Exemplo disso são seus textos maiores, a partir das Lettres philosophiques de 1734, diretamente inspiradas pela estadia na Inglaterra de 1726 a 1729 e construídas como uma defesa da filosofia e da política inglesas - Locke, Newton e a monarquia constitucional - contra a filosofia e a política francesas Descartes e o cartesianismo, Pascal e os contrastes internos à monarquia 
absolutista. E igualmente nos anos sessenta Voltaire no Tratado sobre a tolerância parte do trágico e controverso caso judiciário de Jean Calas, o comerciante huguenote de Toulouse condenado à morte em $1762 \mathrm{com}$ a acusação de ter assassinado o filho, para promover uma batalha em defesa da tolerância religiosa e contra toda forma de fanatismo e de obscurantismo; ou ainda rearticula no Dicionário filosófico (1764) a luta contra a "infâme" nos limites de um modelo compactamente racionalista que encontra no deísmo e na crítica às religiões históricas o seu aspecto moral e filosófico.

No caso das Ideias republicanas Voltaire segue um modelo em muitos aspectos semelhante, pois se a obra encontra inegavelmente seu terreno de cultura nas polêmicas genebrinas de seu tempo, ela também permite a seu autor se confrontar com as hipóteses políticas de Rousseau e de Montesquieu e repropor o ideal de tolerância, que se mostra central na especulação teorico-política daqueles anos.

Os problemas de datação ligados a este texto parecem resolvidos depois que Peter Gay, contestando uma longa tradição crítica que se apoiava na autoridade das três maiores edições das obras de Voltaire (Kehl, Beuchot e Moland) e na do maior bibliógrafo voltairiano, Georges Bengesco todas datavam a obra de 1762, devido às críticas contra o Contrato social de Rousseau, que surgiu naquele mesmo ano ${ }^{5}$ - levou, com uma série de argumentações convincentes, a publicação deste pequeno volume ao ano de $1765 .^{6}$

As Ideias republicanas nascem em plena polêmica política genebrina. Voltaire, que em 1763 toma posição contra os parlamentos franceses - e em particular contra o de Toulouse - em seu Tratado sobre a tolerância e que, em 1764-65, se alinha contra o consistório genebrino que tinha condenado "o fornicador Covelle", intervém ativamente na crise política que em 1765 contrapõe "négatifs" e "représentants". Numa Genebra à beira da guerra civil, ele se põe como mediador entre os dois partidos, recebendo em Ferney, em novembro daquele ano, emissários de ambas as partes. Redige, além disso, sob a solicitação de alguns magistrados, uma proposta de pacificação que envia em 25 de novembro a D'Argental, antes de apresentá-la, como é sua intenção, ao Pequeno Conselho. ${ }^{7}$ Ora, esta breve proposta de mediação política - Propositions à examiner pour apaiser les divisions de Genève - publicada pela primeira vez em 1908 por Fernand 
Caussy $^{8}$ - oferece uma série de surpreendentes semelhanças com as Ideias republicanas. É então provável que estas últimas tenham sido escritas naquele mesmo arco temporal e tenham sido impressas entre novembro e dezembro daquele mesmo ano de 1765. No mais, em janeiro de 1766, Grimm em sua Corréspondance littéraire nos informa que

"o gênio que reside em Ferney encontra agora o momento oportuno para dizer sua opinião sobre as querelas que dividem a república de Genebra. Ele publicou, sempre escondido de nós, um pequeno escrito de quarenta e cinco páginas in $-8^{\circ}$ grande, intitulado Ideias republicanas por um membro do corpo. Este escrito não é agradável. Ele contém ideias muito sensatas, e sem entrar nos detalhes das intrigas genebrinas, propõe partidos bem moderados. Ele retoma diversas passagens do Contrato social do Sr. Rousseau e do Espírito das leis de Montesquieu."'

Este problema da datação das Ideias republicanas não é de pouco valor, na medida em que Voltaire muda nos anos sessenta a sua posição em relação à república genebrina. O julgamento sobre Genebra - cidade tendencialmente deísta e na qual viriam a prosperar vários filósofos - é em parte redimensionado já no final dos anos cinquenta, e muda também a originária atitude filoaristocrática de Voltaire. Ele abandona sua inicial adesão a favor dos "négatifs" para se aproximar das posições dos "représentants" e para se deslocar ulteriormente, depois de 1766, até abraçar a causa dos "natifs". De tal modo, como se afirmou, "se Voltaire tivesse escrito as Ideias republicanas em 1762 elas seriam mais conservadoras, se o tivesse escrito depois de 1766, elas seriam mais radicais do que de fato são." ${ }^{10}$

Nascidas em meio ao debate político genebrino, as Ideias republicanas não parecem, em todo caso, desmentir o pragmatismo e o relativismo político de seu autor que jamais cansou de defender a liberdade inglesa e a monarquia constitucional britânica, mas que ao mesmo tempo apoiou na França o absolutismo monárquico com função anti-nobiliárquica, defendeu o despotismo ilustrado de Frederico II na Prússia e de Catarina II na Rússia e, em Genebra, o governo republicano e as posições burguesas dos "représentants". As Ideias republicanas refletem, de qualquer modo, a aversão do Voltaire daqueles anos para com a aristocracia genebrina e para com o ressurgimento de todo tradicionalismo confessional. Além disso, a 
obra, escrita "pelo membro de um corpo" - como se recorda no título remete imediatamente aos debates internos a Genebra, mas alude também a um comportamento mais geral de Voltaire em defesa da liberdade de pensamento e de expressão.

As posições dos "représentants" já tinham sido incorporadas por Rousseau nas Cartas escritas da montanha, publicadas em dezembro de 1764 em resposta às Cartas escritas do campo, do procurador geral Jean Robert Trochin (1763). Mas certamenteVoltaire não quer ser confundido com seu antagonista Jean-Jacques; assim, se toma posição contra a condenação do Contrato social realizada pelo Conselho genebrino dos Vinte e cinco em junho de 1762, apresenta também uma série de críticas à obra rousseauniana na qual discerne perigosas doutrinas sociais, capazes até mesmo de levar à anarquia. Assim, a defesa absolutamente necessária da liberdade de expressão não se une a nenhuma indulgência em relação ao autor genebrino, como quando afirma a propósito do Contrato social que "queimaram este livro. O processo de queimá-lo foi tão odioso quanto aquele de compô-lo"; embora, em todo caso, ele recorde que "se esse livro era perigoso, seria preciso refutá-lo." (VOLTAIRE, 1961, p. 515) Mas os elementos polêmicos - tanto ligados à cidade de Genebra, quanto relativos às obras de Rousseau ou de Montesquieu - são colocados em uma moldura mais geral que parte da denúncia do despotismo ( $\mathbb{I}$ I) para chegar à teorização da tolerância ( $($ LXIV-LXV). Os sessenta e cinco parágrafos ou pequenos capítulos de que se compõe a obra esboçam de tal modo um quadro articulado em que a polêmica política se une à religiosa, ou melhor, em que se passa imediatamente de uma a outra.

III. O processo de Voltaire nas Ideias republicanas consiste em passar continuamente do particular ao geral, aproveitando os casos genebrinos para articular um discurso político autônomo. Mas a estrutura desta obra, que mantém intacto este modelo expositivo, permite a identificação de pelo menos quatro núcleos temáticos. Aos primeiros parágrafos relativos ao despotismo e à república genebrina (\$ I-XXVIII), liga-se uma segunda parte dedicada à crítica do Contrato social de Rousseau ( $\mathbb{X}$ XXIXXXXIX). Segue-se um núcleo de parágrafos - do XL ao L - que retorna a temas relativos à república genebrina, ainda que apresentando opiniões 
de ordem mais geral, e encontra-se, por fim, uma última seção em que Voltaire se confronta com o Espírito das leis de Montesquieu e repropõe a ideia universal de tolerância ( $\mathbb{L}$ LI-LXV).

O texto começa com uma definição do despotismo, indicado como um "castigo" ligado à incapacidade humana de se autogovernar. ${ }^{11}$ Mas esta condenação da arbitrariedade do despotismo e da sujeição é imediatamente seguida por uma análise de "o mais absurdo dos despotismos, o mais humilhante para a natureza humana [...] o mais funesto, [...] o dos padres; e de todos os impérios sacerdotais, o mais criminoso é sem dúvida o dos padres da religião cristã. É um ultraje feito ao nosso Evangelho." (VOLTAIRE, 1961, p. 504).

A partir destas afirmações retorna o clima polêmico próprio doVoltaire dos anos sessenta em que a crítica religiosa contra a "infâme" se mostra momento central e imprescindível da batalha político-cultural. Não é por acaso que tais passagens deveriam ser lidas junto com as asserções semelhantes de que estão repletos outros textos daqueles anos como o Tratado sobre a tolerância ou o Dicionário filosófico. A crítica, então, se estende a Roma e ao papado que "impuseram, ao mesmo tempo, sua dominação e seu secto odioso à metade da Europa" (Id., ibid., p. 504); e pouco depois se recorda, com uma referência direta a Genebra, como foi destruída "em nossa cidade uma parte das superstições papais” (Id.,ibid., 505) quando em 1534 o bispo Pierre de la Baume foi expulso. O elogio de Genebra prossegue lembrando como "esta liberdade" fora "comprada com nosso sangue" e produzira aquele regime político republicano singular baseado na igualdade:

"Não conhecemos nada desta distinção odiosa e humilhante entre nobres e plebeus, que em sua origem não significa nada além de senhores e escravos. Nascemos todos iguais e continuamos assim; e demos as dignidades, quer dizer, os fardos públicos, àqueles que nos pareceram mais próprios para sustentá-los”. (Id., ibid., p. 505)

E nesta defesa da república suíça parece ecoar a idealização da liberdade genebrina que Voltaire tinha enunciado dez anos antes, quando se encontrava em "Les Délices", em alguns versos: "Não desmerecemos os trabalhos necessários: / Os estados são iguais, e os homens são irmãos." (VOLTAIRE, 1877-1882, X, p. 365). 
Mas as alusões a Genebra e a sua situação política reaparecem mais vezes na obra. Voltaire assume, muitas vezes, posição a favor dos "représentants", criticando os magistrados genebrinos e invocando uma clara distinção entre governo civil e eclesiástico ("é preciso dizer governo civil e regulamentos eclesiásticos”). (VOLTAIRE, 1961, p. 506). Além disso, fazendo sua uma das reivindicações dos "représentants", Voltaire afirma que "quando uma lei é obscura é preciso que todos a interpretem, já que todos a promulgaram; a não ser que se tenha expressamente encarregado alguns para interpretá-las”. (Id., ibid., p. 507). E ainda, frisando a diferença da situação histórica entre os tempos que viram o nascimento da república genebrina e aqueles atuais, recorda que "a lei que permitisse prender um cidadão sem informação prévia e sem formalidade jurídica seria tolerável numa época de confusão e de guerra; ela seria injusta e tirânica em tempos de paz". (Id., ibid., pp. 507-508) Assim, toda autoridade eclesiástica deveria se limitar a fornecer preceitos morais, ${ }^{12}$ e, em uma alusão direta ao caso de Robert Covelle, lembra que "uma assembleia eclesiástica que pretendesse fazer um cidadão ajoelhar diante de si, assumiria o papel de um pedagogo que corrige as crianças ou de um tirano que pune os escravos." (Id., ibid., pp. 505-506).

Mas para Voltaire a Genebra republicana deve ser antes o reino da liberdade que o da igualdade, antes Atenas que Esparta, e ele tenta fazer valer também na república suíça os ideais políticos liberais que encontram o desenvolvimento e a prosperidade humana no respeito das leis, nos progressos do comércio e na tolerância religiosa. Donde a crítica às leis suntuárias que "só agradam aos desocupados indigentes" (Id., ibid., p. 508) e a afirmação de que

"uma lei suntuária, que é boa numa república pobre e destituída de arte, fica absurda quando a cidade tornou-se industrial e opulenta. É privar os artistas do ganho legítimo que teriam com as riquezas; é privar aqueles que têm fortunas do direito natural de gozá-las; é asfixiar toda indústria, é vexar, num só tempo, os ricos e os pobres." (Id., ibid., p. 508).

E mais, a ideia do crescimento da indústria e da atividade humana se une à da importância de uma prática de tolerância capaz de pôr fim aos dogmas religiosos, não sem algumas alusões pessoais relativas à impossibilidade, para quem não era genebrino, de comprar propriedades no 


\section{4}

território da república. Mas todo o trecho deste parágrafo XXIV assume uma importância central, na medida em que exprime plenamente a filosofia política voltairiana e a intensa ligação entre ideais de tolerância e de progresso civil:

"Se uma república se formou em meio a guerras de religião, se durante essa confusão expulsou de seu território seus sectos inimigos, conduziu-se sabiamente, já que, então, se veria como um país rodeado de peste, e que recearia que lhe levassem a peste. Mas, uma vez que estes tempos de vertigem passaram, e que a tolerância se tornou o dogma dominante de todas as pessoas honestas da Europa, não é uma barbaridade ridícula perguntar a um homem que acabou de se estabelecer e trazer suas riquezas para nosso país: "Senhor, a que religião pertence? O ouro e a prata, a indústria e o talento, não são de nenhuma religião." (Id., ibid., p. 509).

O dinheiro e a atividade não têm religião para Voltaire, aliás, permitem a convivência entre as diversas religiões. Em relação a isto, o filósofo de Ferney permaneceu fiel à hipótese apresentada trinta anos antes na sexta das suas Cartas filosóficas (1734), em que, falando da bolsa de Londres, exprimia a convicção que o comércio poderia efetivamente derrotar as divisões irracionais produzidas pelas religiões, educando os cidadãos para as liberdades civis e para a prosperidade e permitindo àqueles que professam as religiões mais diversas viver "em paz e felizes". ${ }^{13}$ A bolsa, que aumenta a circulação das mercadorias, é o lugar emblemático de uma tolerância baseada em uma nova dinâmica social e que mira à felicidade das nações. Nesta perspectiva, comércio e tolerância estão intimamente unidos, na medida em que se nutrem reciprocamente um do outro. A importância que Voltaire atribui ao trabalho, seguindo o exemplo de Locke, à propriedade privada e às trocas econômicas tem como corolário a exigência totalmente prática - e não só moral e civil - de uma tolerância capaz de limitar as trágicas consequências produzidas pelo fanatismo e por todo absurdo e incompreensível litígio teológico.

É esta liberdade inglesa que Voltaire pretende transferir também para Genebra e que encontra sua afirmação máxima na liberdade de pensamento e de expressão: "numa república digna desse nome, a liberdade de publicar seus pensamentos é um direito natural do cidadão (...) tal é a lei 
da Inglaterra, país monárquico, mas onde os homens são mais livres que alhures, pois eles são esclarecidos." (Id., ibid., p. 509).

As alusões a Genebra são ainda explícitas em outros passos, como quando afirma que "de todas as repúblicas, a menor deveria parecer ser a mais feliz, quando sua liberdade é garantida por sua situação e é do interesse de seus vizinhos conservá-la”. Mas se recorda também como o orgulho unido ao desejo de comandar os próprios semelhantes - "a paixão dominadora do espírito humano" - fazem, às vezes, com "que um pequeno Estado" seja "mais confuso que um grande". (Id., ibid., p. 509) E o remédio para esta situação consiste apenas na razão, como capacidade de mediação e de superação das paixões contrapostas. ${ }^{14}$

Se, depois, passamos a considerar os dez parágrafos relativos à crítica ao Contrato social (XXIX-XXXIX), surge imediatamente o contraste radical entre um Voltaire defensor do modelo inglês e o democrático Rousseau, emblematicamente formalizável na distância entre quem procura na sociedade o desenvolvimento do comércio e das artes e quem, ao contrário, vê nestes últimos decadência e corrupção. Assim, à hipótese de uma república virtuosa e igualitária delineada no Contrato social Voltaire contrapõe a de um estado que encontra na circulação do dinheiro o seu elemento propulsivo $^{15}$ e define como "extravagante" a afirmação rousseauniana segundo a qual "num estado verdadeiramente livre, os cidadãos fazem tudo com suas próprias mãos, e nada com o dinheiro." (Id., ibid., p. 511) ${ }^{16}$. Mas o filósofo de Ferney não pode aceitar a ideia rousseauniana de que "os depositários do poder executivo", enquanto oficiais e não patrões do povo, possam ser por este nominados ou destituídos a seu prazer. Aliás, ele percebe nestas afirmações "o código da anarquia" - "não temos o direito de destituir os oficiais do Estado quando queremos: isso seria sinal de anarquia" - e lembra como "o próprio rei da França, quando deu as provisões a um magistrado, só pode destituí-lo por meio de um processo" e do mesmo modo o rei da Inglaterra não pode revogar uma dignidade que concedeu. (Id., ibid., p. 512) ${ }^{17}$

Voltaire, de resto, não só não compartilha - e tampouco compreende - a ideia rousseauniana de "vontade geral", mas também contesta as afirmações do Contrato social em que a superioridade do governo republicano em relação ao monárquico é defendida, acusando Rousseau de não ser "prudente e imparcial, como as próprias leis que ele faz falar." 
(VOLTAIRE, 1961, p. 513) ${ }^{18}$. Mas ao mostrar a própria equidistância entre monarquia e república, e ao equiparar estas duas formas de governo "Confessamos com dor que tanto nas repúblicas quanto nas monarquias, a intriga chega aos cargos elevados [...] Não insultemos nem as monarquias, nem as repúblicas" (Id., ibid.) - o autor das Ideias republicanas se põe em uma posição de efetiva distância em relação ao filósofo genebrino. Assim, a distância política entre o democrático Rousseau e o pragmático Voltaire resulta, em todo caso, irreparável. Para o filósofo francês, no Contrato social "não há uma página onde não encontremos erros ou contradições" (Id.,ibid., p. 514); além disso, nesta obra, no capítulo sobre a religião civil $(I V, 8)$, são apresentadas afirmações que não se diferenciariam das de Bayle sobre a impossibilidade de uma sociedade de verdadeiros cristãos subsistir efetivamente. Rousseau não teria feito nada senão tentar superar Bayle repetindo tudo quanto este último já dissera a propósito da religião, como quando afirma no Contrato social que "uma sociedade de verdadeiros cristãos não seria mais uma sociedade de homens." (Id., ibid., p. 515). ${ }^{19}$

Nesta crítica da religião civil de Rousseau situa-se talvez o ponto de máxima oposição entre os dois pensadores. O deísmo de Voltaire só reconhece na religião civil do Contato social elementos baylianos, com a reapresentação de uma espécie de "sociedade ateia”, em que é impossível para quem segue o cristianismo uma vida social efetiva. $\mathrm{O}$ elemento democrático e republicano que condiciona com força a instância civil de Rousseau é visto como uma aproximação a posições perigosamente heterodoxas e, de fato, o deísmo voltairiano que se identifica com uma espécie de cristianismo racional e a-histórico, reduzido a simples moral e privado de dogmas e de sacramentos, está certamente distante da religião civil rousseuaniana que vê o cristianismo - que prega servidão e dependência - em oposição aos ideais republicanos.

Assim, o filósofo francês, embora assuma a defesa de seu antagonista em nome da liberdade de pensamento e de expressão, não renuncia ao desprezo e à ofensa em sua crítica ao autor do Contrato social; não por acaso as acusações a Rousseau, certamente condicionadas pelas polêmicas daqueles anos, formalizam uma ruptura então definitiva entre Voltaire (e, mais em geral, o ambiente dos "philosophes") e o pensador genebrino. 
IV. O conjunto de dez parágrafos - do XL ao L - que se pode indentificar como o terceiro núcleo da obra volta, porém, a tratar temas relativos à república genebrina. Recorda-se, por exemplo, da importância dos tribunais que não devem ser arbitrários, na medida em que "um tribunal deve ter leis fixas tanto para o criminoso quanto para o civil" (Id., ibid., p. 515), e reforça a absoluta necessidade de "um código penal" para os cidadãos como para os magistrados. ${ }^{20}$ Mas nestas páginas emergem também apreciações de ordem mais geral dignas de uma atenção acurada.

Assim, o relativismo voltairiano que emerge na afirmação de que nunca houve governos perfeitos, na medida em que os homens são dominados pelas paixões - "nunca existiu um governo perfeito, porque os homens têm paixões; se eles não tivessem paixões, não precisaríamos de governo" -, transforma-se, logo em seguida, numa defesa do governo republicano: "o mais tolerável de todos é sem dúvida o republicano, porque é o que mais aproxima os homens da igualdade natural". (Id., ibid., p. 516) EVoltaire afirma ainda que "uma república protestante deve ser um duodécimo mais rica, mais industrial, mais populosa que uma república papal" (Id., ibid., p. 517), na medida em que não só há trinta dias de festas a mais num país papista (que representam a duodécima parte de um ano), mas também uma parte da população (o clero) é inativa e não contribui para o bem econômico da sociedade. ${ }^{21}$ Além disso, o parágrafo XLIX realiza uma verdadeira defesa da Suíça, país habitado por pessoas ativas e ilustradas. Trata-se de um elogio do país helvético, cuja prosperidade é posta em confronto com a degradação que reina no Estado do Papa:

"Metade do território da Suíça é composto de rochas e de precipícios, e a outra é pouco fértil; mas quando mãos livres, conduzidas por espíritos esclarecidos, cultivaram essa terra, ela se tornou florida. O país do papa, ao contrário, de Orvieto a Terracina, num espaço de mais de cento e vinte milhas de distância, é inculto, inabitado, e insalubre devido à pobreza; pode-se viajar por lá um dia inteiro sem encontrar homens, nem animais; há mais padres que agricultores; não se come outro pão além do pão ázimo.” (Id., ibid., p. 518).

Um parecer semelhante sobre a desastrosa situação do estado pontifício - um misto tipicamente voltairiano de sarcasmo, ironia e piedade - é encontrado em um texto do fim dos anos sessenta, As cartas de Amabed 
(1769). A entrada de Amabed nos territórios do papa e sua viagem de Civitavecchia para Roma permite uma descrição deprimente daqueles campos afligidos pela miséria, pela doença e pela corrupção, onde as poucas pessoas que os habitam vivem miseramente, nutrindo-se apenas "de pequenos pães achatados que lhes dão gratuitamente pela manhã” e não bebendo "senão água benta". (VOLTAIRE, 1979, p. 510) As afirmações sobre a maior riqueza e prosperidade de um país protestante em relação a um católico sentem os efeitos, com toda probabilidade - no vínculo entre religião, demografia e desenvolvimento econômico -, das concepções montesquieanas que, tanto em algumas das Cartas persas (cartas CXIICXXII), quanto nos livros XXIV e XXV do Espírito das leis (em particular XXIV, 5, para a correspondência entre religião católica-monarquia e religião protestante-república), põem em íntima relação crença religiosa, clima, composição demográfica e estrutura política de cada país. ${ }^{22}$

Depois deste elogio da Suíça e da república, Voltaire retorna ainda no parágrafo L a falar de Genebra, recordando como muitas vezes numa república são necessários mediadores - "talvez não seja tão detestável, tal como cremos, que uma república necessite de mediadores" - e lembrando da importância da interpretação da lei de "árbitros que esclareçam as leis contestadas, que as modifique, se for preciso, e que evite, tanto quanto for possível, novas mudanças". E esta procura pelo equilíbrio e pela estabilidade "será a obra prima da razão e da imparcialidade". (Id., ibid., pp. 518-519) A última parte das Ideias republicanas examina a questão central: Montesquieu.Voltaire se contrapõe ao autor do Espírito das leis, cujas opiniões discute ainda em outras obras, em particular no verbete "Leis (Espírito das)" das Questões sobre a Enciclopédia (iniciadas em 1770) e no Comentário sobre o Espírito das Leis, publicado em 1777, um ano antes de sua morte. ${ }^{23} \mathrm{~A}$ avaliação geral que emerge das páginas da obra de 1765 é contraditória, mas, no fim das contas, positiva: o Espírito das leis seria um "livro defeituoso", mas "cheio de coisas admiráveis" (Id., ibid., p. 524), enquanto a maior limitação desse texto consiste no fato de seu autor não ter sabido "submeter seu gênio à ordem e ao método necessário"; uma falta de ordem e de método que se transferiria também na reconstrução histórica e na inexatidão das citações, de modo que "quando cita, confunde, com frequência, sua imaginação com sua memória”. (Id., ibid., p. 529). ${ }^{24}$ 
Voltaire não só critica Montesquieu por suas citações erradas ou que desviam do correto, ou por seus erros históricos ou geográficos (Id., ibid., pp. 522-523), mas também recusa a utilização que ele fez de fontes como as anotações de viagem, que resultariam completamente não essenciais - como é o caso do escrito de P. Rycaut sobre o Império Otomano na economia mais geral do texto. Assim, as contínuas alusões às leis de Bornéu, de Pegu, da China ou às de outras populações orientais seriam ineficazes e dispersivas dado que "um viajante frequentemente diz coisas que um homem que escreve como legislador não pode nunca repetir". (Id., ibid., p. 522). ${ }^{25}$ Uma obra de legislação requer, de fato, maior rigor e cautela e não deve utilizar "nem conjeturas casuais, nem exemplos tirados de povos desconhecidos, nem extravagâncias de estilo, nem digressões que não dizem respeito ao assunto." (Id., ibid., p. 523). ${ }^{26} \mathrm{~A}$ falta de método se uniria, assim, a hipóteses e conjeturas sem fundamentos - como a ideia de que a honra seja própria da monarquia e não da república (Id., ibid., p. 519) - e a digressões inúteis, com a consequência que neste texto se encontraria eventualmente "o espírito do autor, que está bastante presente, e raramente o espírito das leis." (Id., ibid., p. 523). ${ }^{27}$ As afirmações críticas sobre a honra mostram, além disso, como o ideal monárquico de Montesquieu, baseado nos poderes intermédios da aristocracia, do clero e da nobreza de toga, estava distante do modelo de monarquia absolutista que Voltaire vê se configurar na França a partir do reino de Luís XIV, como monarquia essencialmente anti-nobiliar.

Mas neste julgamento desfavorável, de modo geral, em relação ao Espírito das leis - que remete mesmo assim a uma substancial incompreensão por parte de Voltaire da complexa articulação epistemológica e histórica deste texto - surgem algumas apreciações esclarecedoras. Assim, “este livro defeituoso é cheio de coisas admiráveis", se é verdade que "os fanáticos o insultaram justamente nos pontos que merecem os agradecimentos do gênero humano." (Id., ibid., p. 524). ${ }^{28}$ E ainda, "apesar dos defeitos, esta obra deve ser sempre cara aos homens, porque o autor disse sinceramente o que pensa [...] Por todo o livro, ele lembra os homens que eles são livres; apresenta à natureza humana seus títulos, que ela perdeu na maior parte da terra; combate a superstição; inspira a moral." (Id., ibid.).

A obra de Montesquieu, ainda que com todos os seus limites, destruindo a superstição e promovendo a virtude, seria capaz de "tornar os 
homens melhores". (Id., ibid.). No programa todo iluminista de liberação dos árbitros da tirania, seja política, seja religiosa, o Espírito das leis ocupa, então, um lugar central: é um daqueles livros que preserva os jovens "de toda espécie de fanatismo" e que lhes faz compreender que "a paz é o fruto da tolerância e o verdadeiro objetivo de toda sociedade". (Id., ibid.) Uma tolerância, conclui Voltaire, que "é tão necessária na política quanto na religião." 29

De resto, a relação instaurada porVoltaire entre a obra de Montesquieu e o tema da tolerância reaparece naqueles anos em outros escritos. No Tratado sobre a tolerância, de fato,Voltaire se vê em sintonia com o Presidente sobre este mesmo tema. O Tratado se refere uma única vez, no capítulo XV ("Testemunhos contra a intolerância"), em que é citado um trecho do Espírito das leis (XXV, 13). ${ }^{30}$ Trata-se de uma carta que Montesquieu imagina ter sido escrita por um judeu aos inquisidores, na qual se testemunha a desumanidade de toda violência e assassinato cometidos em nome da religião, e que constitui um dos capítulos mais lúcidos e intensos de toda obra.

Ora, na arquitetura das Ideias republicanas as afirmações conclusivas sobre a tolerância se mostram centrais e constituem o momento teórico e político em que Voltaire propõe algo. A partir do tema da tolerância,já situado no Espírito das leis, Voltaire chega, de fato, a tornar peremptória a função política desta categoria que ele considera uma conquista irrenunciável de sua época e um modelo universal, capaz de agir transversalmente dentro de práticas políticas e institucionais diferentes: da monarquia constitucional inglesa ao absolutismo monárquico francês até o governo republicano.

V. Certamente, recordando a absoluta centralidade do tema da tolerância em Voltaire, não se pretende minimizar a pessoal adesão do autor das Ideias republicanas aos ideais que ele vê expressos em Genebra, nem subestimar os deslizamentos progressivos que levam o patriarca de Ferney a abandonar toda simpatia filoaristocrática, para chegar a se opor ao patriciado e a se aproximar, enfim - como emerge de uma série de testemunhos, entre os quais uma carta a d'Argental de 14 de outubro de 1765 - a posições democráticas. ${ }^{31}$ Mais que a um nível abstratamente normativo, a política de Voltaire parece, de fato, ater-se a um modelo de praticidade e de 
consistência, necessariamente móvel e pragmático, que mira à defesa de instâncias gerais exprimíveis na liberdade de pensamento, na luta contra o fanatismo e na tolerância. E para o Voltaire dos anos sessenta a batalha pela tolerância é o momento central de toda sua propaganda política e religiosa.

O Tratado sobre a tolerância, as Ideias republicanas e o Dicionário filosófico exprimem todos, dentro de estratégias polêmicas às vezes divergentes, ligadas a ocasiões que inspiraram a redação destes textos, a importância teórica e cultural da categoria de tolerância. E instâncias semelhantes reaparecem nos contos filosóficos daqueles anos: de O Ingênuo (1767) ao O homem de quarenta escudos (1768), do A princesa da Babilônia (1768) às Cartas de Amabed (1769). Voltaire naqueles anos é um filósofo militante em luta contra os preconceitos e o fanatismo, mas capaz ao mesmo tempo de redefinir a própria ideia de religião. Seu deísmo, não isento, é claro, de uma inevitável abstração, se traduz constantemente em tensão crítica em relação às religiões históricas e em particular ao catolicismo, considerado como um perigosíssimo amontoado de intolerância e de perseguição. A luta contra "l'infâme" se torna o objetivo prioritário, e Voltaire elabora uma estratégia filosófica plena contra a Igreja e a superstição, em nome de uma razão que encontra as bases da tolerância na convivência entre confissões diferentes e em uma ideia toda humana de religião, entendida - é esta a indicação que nos vem do Tratado sobre a tolerância - como recíproca compaixão e aceitação. ${ }^{32}$ Assim, a tolerância se baseia na fraqueza e na inconstância do homem, em sua constante queda no erro, e este limite antropológico se transforma numa noção de razão capaz de livrar a filosofia de toda ilusão metafísica, privando-a de qualquer miragem salvífica: "o filósofo - como afirma no Dicionário filosófico no verbete "Filósofo" - não é entusiasta, não se arroga o direito de profeta, não se diz inspirado pelos deuses." (VOLTAIRE, 1994, II, p. 433).

Sem dúvida, dentro desta estratégia a favor de uma tolerância universal, a política é reabsorvida no interior desta mesma prática de tolerância, em que o realismo e o pragmatismo se dão melhor que toda abstração programática. Assim, naqueles mesmos anos, o ideal de tolerância parece realizável para Voltaire, quer por uma monarquia absolutista que se exprime, na França, contra as instâncias nobres e locais representadas pelos parlamentos, como aquele ultra-católico e fanático de Tolouse (e é este o caso do Tratado sobre a tolerância), quer pela obra de mediação entre "négatifs" 
e "représentants" que se exprime, na república genebrina, numa escolha explicitamente filo-burguesa e antiaristocrática, e num ideal de religião racional (e é este o caso das Ideias republicanas). E certamente a experiência genebrina - com o progressivo deslocamento político de Voltaire que antes se põe como mediador a favor da causa burguesa dos "représentants", e depois apoia a causa popular dos "natifs" - emerge também em outros textos, como no diálogo L'A. B. C. (1768). Nesta obra, na sexta conversação, de fato parece notar os habitantes e os operários de Genebra e o povo de "natifs", quando toma posição a favor de um governo democrático, no qual o marceneiro, o pedreiro, o artesão se elevam "para além de seus ofícios" e conhecem "o interesse público", e quando afirma que "ser livre, só haver iguais, é a verdadeira vida, a vida natural do homem; qualquer outra é um artifício indigno, uma comédia ruim, onde um assume o papel de mestre, outro de escravo, aquele de Parasita e este de alcoviteiro." ${ }^{33}$

Mas estas oscilações não devem ofuscar o tema da tolerância - religiosa e civil - que representa a verdadeira instância teórica e ética da polêmica filosófica de Voltaire e, ao mesmo tempo, o legado político mais importante que o pensador francês confiou a seu século. Assim, o deslocamento, nas Ideias republicanas, do tema da tolerância em Montesquieu ao da tolerância em geral, que é "tão necessária na política quanto na religião", se mostra ainda mais esclarecedor se for lido com o auxílio de um breve texto publicado poucos meses depois: o Commentaire sur le livre des délits et des peines (1766). Se é verdade que Voltaire lê Beccaria no outono de $1765^{34}$, a redação das Ideias republicanas devia se completar (como sugeriu Gianni Francioni) ${ }^{35}$ no mesmo arco de tempo em que Voltaire chegava a se confrontar com as ideias do pensador italiano. De resto, em seu Commentaire, Voltaire retoma no âmbito do direito penal uma série de indicações relativas à moderação, à proporcionalidade das penas e à separação entre justiça divina e humana, relançando ao mesmo tempo o recurso à tolerância como o melhor meio para manter a paz em um estado e permitir o exercício das várias confissões. ${ }^{36}$

Não é certo supor, portanto, que a ideia de tolerância posta porVoltaire no título de seu Tratado, em 1763, se enriqueça nas Ideias republicanas com os estímulos derivados da leitura de Beccaria. É o próprio filósofo de Ferney a nos lembrar como no momento em que intervém nas polêmicas genebrinas contra os magistrados e a favor dos “citoyens", ele se aproxima 
também da leitura Dos delitos e das penas. Uma carta a Damilaville de 16 de outubro de 1765 é explícita em relação a isto:

“As divisões de Genebra irromperão em pouco tempo. É absolutamente necessário que você e que seus amigos divulguem entre o público que os cidadãos têm razão contra os magistrados; pois é certo que o povo só quer a liberdade e que a magistratura ambiciona um poder absoluto. Há algo mais tirânico do que, por exemplo, acabar com a liberdade de imprensa? E como um povo pode se dizer livre quando não pode pensar por escrito? Qualquer um que tem o poder em mãos gostaria de ofuscar os olhos daqueles que lhe são submissos. Todo juiz de cidade gostaria de ser despótico. A fúria da dominação é uma doença incurável”.

E imediatamente em seguida se lê: "Comecei a ler hoje o livro italiano sobre delitos e penas. À primeira vista ele me parece filosófico; o autor é um irmão." 37

Voltaire, "o homem de Calas", Voltaire polemista, homem de ação e defensor em Genebra da causa republicana, é também leitor atento, interlocutor e comentador da obra de Beccaria, um texto em que o pensador milanês se faz, tanto quanto o filósofo francês, partidário dos "interesses da humanidade". 38

${ }^{1}$ Cf. R. Naves, Voltaire et l'Encyclopédie, Paris 1938, pp. 38-45 e P. Alatri, Voltaire e Ginevra, in Ginevra e l'Italia, coletânea de estudos promovida pela Faculdade valdense de Teologia de Roma, com organização de D. Cantimori, L. Firpo, G. Spini, F.Venturi,V.Vinay, Firenze 1959, pp. 615-649, em particular pp. 627-630.

${ }^{2}$ D 6821 (indica-se com D seguido pelo número correspondente da letra a edição definitiva da correspondência de Voltaire: Voltaire, Correspondence and related documents, ed. by Th. Besterman, in CEuvres complètes de Voltaire, t. 85-135, Oxford 1968-1977).

${ }^{3}$ Sobre a situação política da república genebrina nos limitamos a recordar: N. Matteucci, Jacques Mallet-Du Pan, Napoli 1957, em particular parte I, cap. II "Ginevra e la querelle Rousseau-Voltaire", e cap. III "Rousseau e Voltaire e le rivoluzioni ginevrine", pp. 29-108; P. Alatri, Voltaire e Ginevra, cit.; P. Gay, Voltaire's politics: the poet as realist, Princeton 1959, em partiular o cap. IV sobre Genebra; G. Silvestrini, Alle radici del pensiero di Rousseau. Istituzioni e dibattito politico a Ginevra nella prima metà del Settecento, Milano 1993.

4 Para uma diferenciação precisa entre "sujets", "habitants" e "natifs" cf. P. Gay, Voltaire's "Idées républicaines": a study in bibliography and interpretation, "Studies on Voltaire", v. 6, 1959, 
pp. 67-105, em particular p. 77 (mas o artigo todo resulta central para uma análise das Ideias republicanas). Cf. também F. Caussy, Voltaire pacificateur de Genève, "Revue politique et littéraire. Revue blue",V s., t. IX, n. 1, 4 janvier 1908, pp. 9-13, p. 10.

${ }^{5}$ Cf. G. Bengesco, Voltaire. Bibliographie de ses auvres, 4 voll., Paris 1882-1890, vol. II, 1885, n. 1679, pp. 111-112: "nas Ideias republicanas, etc., Voltaire critica muitas passagens do Contrato Social de J.-J. Rousseau; ora, o Contrato Social apareceu em 1762 [...] As Ideias republicanas devem ser, então, de 1762, e é também de 1762 que os editores de Kehl dataram este opúscolo que eles intitularam: Ideias republicanas por um cidadão de Genebra (veja o tomo XXIX, pp. 185208). Entretanto, Grimm fala de Ideias republicanas, como de uma obra nova, em 15 de janeiro de 1766 ”. Cf. também P. Gay,Voltaire's "Idées républicaines”, cit., pp. 68-69.

${ }^{6}$ Para a datação deste texto, cf. P. Gay, Voltaire’s “Idées républicaines”, cit., e Id., Voltaire's politics: the poet as realist, cit., "Appendix II".

7 Cf. D 13001: "escrevi um pequeno projeto de pacificação que me parece claro e muito fácil de ser compreendido por aqueles que não estão a par das leis da minúscula república de Genebra ". Cf. também a carta de Voltaire a J.A. de Luc de 22 de novembro de 1765 (D 12996).

${ }^{8}$ Cf.Voltaire, Propositions à examiner pour apaiser les divisions de Genève, em apêndice a F. Caussy, Voltaire pacificateur de Genève, cit., pp. 13-15.

${ }^{9}$ Cf. F.M. Grimm, Correspondance littéraire, philosophique et critique, par M. Tourneux, 16 v., Paris 1877-1882, v.VI, pp. 474-475. Já N. Matteucci em sua obra de 1957 sobre J. Mallet-Du Pan contestava a hipótese de datação de Bengesco e reenviava as Ideias republicanas para janeiro de 1766, apoiando-se no testemunho de Grimm. Cf. N. Matteucci, Jacques Mallet-Du Pan, cit., p. 92 nota.

${ }^{10}$ Cf. P. Gay, Voltaire's "Idées républicaines", cit., p. 103.

11 “o despotismo puro é a punição da pior conduta dos homens. Se uma comunidade de homens é dominada por um só ou por alguns, é visivelmente porque ela não teve a coragem nem a habilidade de governar a si mesma." (VOLTAIRE, 1961, p. 503).

${ }^{12}$ Cf.: "instituímos os padres a fim de que fossem unicamente aquilo que devem ser: preceptores morais de nossas crianças. Esses preceptores devem ser pagos e considerados; mas não devem almejar nem jurisdição, nem inspeção, nem honras; eles não devem em nenhum caso se igualar à magistratura." (VOLTAIRE, 1961, p. 505).

13 Cf.: "entre na Bolsa de Londres, este lugar mais respeitável que muitas cortes. Aí verá reunido, para a utilidade dos homens, os deputados de todas as nações; o judeu, o mulçumano e o cristão tratam-se mutuamente como se fossem da mesma religião e só chamam de infiel quem vai a bancarrota (...) Se houvesse somente uma religião na Inglaterra, o despotismo seria algo a temer; se houvesse duas, elas se degolariam; mas existem trinta, e elas vivem em paz e felizes." (VOLTAIRE, 1961, pp, 17-18) Sobre o papel que estas páginas desenvolvem em relação à ideia voltairiana de tolerância, reenvio a L. Bianchi, La tolleranza di Voltaire: religione, morale e giustizia, in V. Dini (org.), Tolleranza e libertà, Milano 2001, pp. 175-198. Sobre a centralidade da tolerância no projeto político voltairiano, cf. M.L. Lanzillo, Voltaire. La politica della tolleranza, Roma-Bari 2000.

doispontos, Curitiba, São Carlos, vol. 9, n. 3, p.45-67, dezembro, 2012 
${ }^{14}$ Cf.: "qual o remédio para esse mal? A razão, que no fim se faz ouvir, quando as paixões estão cansadas de gritar." (VOLTAIRE, 1961, 510).

${ }^{15}$ Cf.: "todo este artigo [do Contrato Social, III, 9] parece pueril e contraditório [...] E como o povo pode ter pão sem que o dinheiro circule? A contradição é evidente." (Id., ibid., 511).

${ }^{16}$ Voltaire se refere aqui ao Contrato social, III, 15.

${ }^{17}$ Voltaire se refere aqui ao Contrato social, III, 18.

${ }^{18}$ Voltaire se refere aqui ao Contrato social, III, 6 .

${ }^{19}$ Voltaire se refere aqui a Contrat social, IV, 8.

${ }^{20}$ Cf.: "um código penal é absolutamente necessário para os cidadãos e para os magistrados (...), pois não serão mais suas vontades que condenarão, mas a lei.” (Idem, ibid., 515).

21 Cf.: "uma república protestante deve ser um duodécimo mais rica, mais industrial, pais populosa que uma república papal, supondo o terreno igual e igualmente bom, pela razão de terem trinta festas num país papal que significam trinta dias de ociosidade e de luxúria; e trinta dias são um duodécimo do ano. Se nesses países papais há um duodécimo de padres, de seminaristas, de monges e de religiosos, como em Colônia, é claro que um país protestante, com a mesma extensão, deve ser um duodécimo mais populoso." (Id., ibid.).

22 Cf. Montesquieu, Lettres persanes, cxii-cxxii, in Id., Euvres complètes, texte présenté et annoté par R. Caillois, 2 v., Paris 1945-1951, v. I, pp. 295-314, Cfr. também a carta lxxv (idem, pp. 258260), em que se discute sobre as causas físicas das opiniões religiosas que mudam em relação ao estado de saúde, de doença ou à constituição fisica do corpo de cada indivíduo. Cf. Ainda Montesquieu, De l'Esprit des lois, in CEuvres complètes, cit., v. II, 1. XXIV-XXV, pp. 714-750 (em particular 1. XXIV, cap. 5, pp. 718-719). Sobre estes temas reenvio a L. Bianchi, Montesquieu e la religione, in D. Felice (org.), Leggere "L'Esprit des lois". Stato, società e storia nel pensiero di Montesquieu, Napoli 1988, pp. 203-227 e Id., Histoire et nature: la religion dans "L'Esprit des lois", in Le temps de Montesquieu, sous la direction de M. Porret et C.Volpilhac-Auger, Genève 2002, pp. 289-304.

${ }^{23}$ Para as críticas de Voltaire ao Espirito das leis, cf. D. Felice, Voltaire lettore e critico dell' "Esprit des lois", in Id., Oppressione e libertà. Filosofia e anatomia del dispotismo nel pensiero di Montesquieu, Pisa 2000, pp. 219-253. Sobre Voltaire e Montesquieu, cf., entre outros, R. Shackleton, Allies and enemies: Voltaire and Montesquieu, in Id., Essays on Montesquieu and on the Enlightenment, ed. by D. Gilson - M. Smith, Oxford 1998, pp. 153-169; J. Ehrard, Voltaire vu par Montesquieu, in U. Kölving-Ch. Mervaud (eds.), Voltaire et ses combats, 2 voll. Oxford 1997, vol. II, pp. 939-951; Sh. Mason, En marge de l' "Esprit des lois": Voltaire et le roman de la monarchie française, ivi, pp. 1279-1288.

${ }^{24} \mathrm{Um}$ julgamento semelhante surge em um outro texto de Voltaire, L'A.B.C., publicado em 1768, em Genebra, com a falsa indicação de data (1762) e de lugar (Londres). Cfr. L'A.B.C., dialogue curieux. Traduit de l'Anglais de Monsieur Huet, A Londres, chez Robert Freemann, 1762, pp. 7-8: "lamento que este livro seja um labirinto sem um fio condutor e que não tenha nenhum método [...] Ele muitas vezes mistura o falso com o verdadeiro, em fisica, em moral, em história”. E cf. p. 10: "o que ainda é revoltante para um leitor minimamente instruído, é que quase todas as citações são falsas; confunde, com frequência, sua imaginação com sua memória."

doispontos, Curitiba, São Carlos, vol. 9, n. 3, p.45-67, dezembro, 2012 
${ }^{25}$ Cf também L'A.B.C., cit., p. 7: "ri-se ainda, já que depois de citar as leis gregas e romanas, ele fala seriamente das de Bantão, de Cochim, de Tonquim, de Bornéu, de Jacarta, de Formosa, como se ele tivesse lembranças fiéis do governo de todos estes países". Para a referência a Rycaut, ff. P. Rycaut, Histoire de l'Etat présent de l'Empire Ottoman [...] traduite de l'Anglois, Paris, Cramoisy, 1670 (a primeira edição inglesa surgiu em Londres em 1668).

${ }^{26}$ Cf. também L'A.B.C., cit., p. 7:" "é curioso que um homem que escreve sobre as leis diga no prefácio que, em sua obra, não se encontra nenhum rasgo de estilo; e é ainda mais estranho que seu livro seja uma coleção de extravagâncias estilísticas. É Michel Montaigne legislador, ele também era do país de Michel Montaigne."

27 Cf. também L'A.B.C., cit., p. 18: "procurava um fio condutor nesse labirinto; esse fio se rompe quase que em cada artigo; fui enganado; encontrei o espírito do autor, que está bastante presente, e raramente o espírito das leis."

${ }^{28}$ Cf. também L'A.B.C., cit., p. 18: "este livro defeituoso é cheio de coisas admiráveis das quais se fizeram detestáveis cópias. Enfim, os fanáticos o insultaram justamente nos pontos que merecem os agradecimentos do gênero humano.”

${ }^{29}$ Sobre a tolerância $c f$. o $\$ lxiv inteiro, p. 524: “a tolerância é tão necessária na política quanto na religião; somente o orgulho é intolerante. É ele que revolta os espíritos, querendo forçá-los a pensar como nós; é a fonte secreta de todas as divisões."

${ }^{30}$ Cf. Montesquieu, De l'Esprit des lois, cit., 1. XXV, cap. 13 "Muito humilde repreensão aos inquisidores da Espanha e de Portugal”, pp. 746-749, e Voltaire, Traité sur la tolérance, in Id., Mélanges, cit., cap. XV “Témoignages contre l'intolérance”, pp. 618-620.

31 Cf. D 12933: "pois importa muito pouco a França que Genebra seja aristocrática ou democrática. Confesso que, no momento, pendo mais à democracia, apesar de meus antigos princípios, porque me parece que os grandes erraram em muitos pontos."

${ }^{32}$ Sobre a ideia propriamente humana da religião deVoltaire reenvio a L. Bianchi, 'Puissent tous les hommes se souvenir qu'ils sont frères': la religione 'umana' di Volatire nel "Traité sur la tolérance", in L. Bianchi - A. Postigliola (org.), Voltaire: religione e politica, Napoli 1999, pp. 41-70. Sobre Voltaire e a religião veja-se o clássico estudo de R. Pomeau, La religion de Voltaire, nouvelle édition revue et mise à jour, Paris 1994.

${ }^{33}$ Voltaire, L'A.B.C., cit., pp. 66-67.

${ }^{34}$ Cf. L. Firpo, Le edizioni italiane del "Dei delitti e delle pene", in Edizione Nazionale delle opere di Cesare Beccaria, dirigida por L. Firpo e G. Francioni, vol. I, Dei delitti e delle pene, org. de G. Francioni, Milano 1984, p. 478: "Foi justamente um visitante de Ferney, o escocês James Macdonald, que em outubro de 1765 levou de presente para Voltaire um exemplar do Dei delitti e delle pene numa das edições abusivas datadas 'Monaco 1764"”; mas cf. o parágrafo 11 inteiro "Il Commentario di Voltaire (1766)", pp. 476-503. Para as relações entre Voltaire e Beccaria cf. também R. Derathé, Le droit de punir chez Montesquieu, Beccaria et Voltaire, in Atti del Convegno internazionale su Cesare Beccaria promosso dall'Accademia delle Scienze di Torino nel secondo centenario dell'opera "Dei delitti e delle pene", "Memorie dell'Accademia delle Scienze di Torino”, s. IV, n. 9, Torino 1966, pp. 85-100; G. Francioni, Prefazione a Voltaire, Commentario sul libro Dei delitti e delle pene, Como-Pavia 1994.

doispontos, Curitiba, São Carlos, vol. 9, n. 3, p.45-67, dezembro, 2012 
${ }^{35}$ Cfr. G. Francioni, Voltaire e Beccaria: una postilla, in F. De Michelis Pintacuda e G. Francioni (org.), Ideali repubblicani in età moderna, Pisa 2002, pp. 259-264.

${ }^{36}$ Sobre o tema da tolerância, cf.Voltaire, Commentaire sur le livre des délits et des peines par un avocat de province, in Id., Mélanges, cit., pp. 769-807, em particular cap. IV “De l'extirpation des hérésies", pp. 774-775 - em que aparecem palavras semelhantes às do Tratado sobre a tolerância; e cf. p. 775: "vocês querem impedir que uma seita arruíne um Estado, pratiquem a tolerância; imitem a sábia conduta que, hoje em dia, têm a Alemanha, a Inglaterra e a Holanda."

37 D 12938. Para um julgamento positivo de Voltaire sobre a tradução francesa de André Morellet da obra de Beccaria, que apareceu em 1766 - "o excelente livro Dos Delitos e das Penas, tão bem traduzido pelo abade Morellet" - cf. a carta de Voltaire a E.-N. Damilaville de 23 de junho de 1766, D 13371.

${ }^{38}$ Cf. C. Beccaria, Dei delitti e delle pene, org. de G. Francioni, cit., "A chi legge”, p. 21.

\section{Referências bibliográficas}

CAUSSY, F. 1908. Voltaire pacificateur de Genève, Revue politique et littéraire. Revue blue,V s., t. IX, n.1, 4 janvier 1908.

D'ALEMBERT.1757. Genève. In: D'ALEMBERT \& DIDEROT

Encyclopédie ou dictionnaire raisonné des sciences, des arts et des métiers, v.VII, Paris.

VOLTAIRE. 1968-1977. Correspondence and related documents, ed. by Th. Besterman. In: CEuvres complètes de Voltaire, t. 85-135, Oxford.

VOLTAIRE. 1961. Idées républicaines par un membre d'un corps. In: Id., Mélanges, préface par E. Berl, texte établi et annoté par J.Van den Heuvel, Paris.

VOLTAIRE. 1877-1882. Euvres complètes, nouvelle édition par L. Moland, 50 v., Paris.

VOLTAIRE. 1979. Les lettres d'Amabed. in Id., Romans et contes, éd. établie par F. Deloffre \& J.Van den Heuvel, Paris.

VOLTAIRE. 1994. Dictionnaire philosophique, sous la direction de Ch. Mervaud, édition critique par A. Brown et al., 2 v.., Oxford. 
